\title{
Sodium deficiency in Canterbury and Central Otago sheep pastures
}

\author{
R.J. ASPINALL ${ }^{1}$, N. MANDALUNIZ ${ }^{2}$, L.J. HIGHT ${ }^{1}$ and R.J. LUCAS ${ }^{1}$ \\ ${ }^{1}$ Plant Sciences Group, Agriculture and Life Sciences Division, P.O. Box 84, Lincoln University \\ ${ }^{2}$ NEIKER - Basque Institute of Agricultural Research and Development, Granja Modelo de Arkaute, P.B. 46, \\ E-01080, Vitoria-Gasteiz, Spain \\ nmandaluniz@neiker.net
}

\begin{abstract}
Sheep diets are likely to be deficient in sodium $(\mathrm{Na})$ if pasture contains less than $0.04 \% \mathrm{Na}$ (lambs and maintenance) or $0.05 \% \mathrm{Na}$ for ewe flushing and lactation. Herbage from four species was sampled in autumn 2002 from 12 sites on a transect south of the Rakaia River from the coast to $110 \mathrm{~km}$ inland. All species had $>0.10$ $\% \mathrm{Na}$ near the coast but browntop and cocksfoot declined to $<0.10 \% \mathrm{Na}$ at $10 \mathrm{~km}$ and $20 \mathrm{~km}$ inland respectively. White clover and ryegrass declined to about $0.10 \% \mathrm{Na}$ at $40 \mathrm{~km}$ and $80 \mathrm{~km}$ respectively. In autumn 2003, soil and herbage samples were collected from 8 farms over a range of distances from the coast. Soil quick test (QT) $\mathrm{Na}$ from the 8 farms had a strong negative correlation with distance from the sea. Soil QT Na was $<5$ at $40 \mathrm{~km}$ inland and declined to 2 at Mt Grand in the Upper Clutha basin $150 \mathrm{~km}$ from the east coast. The herbs, plantain and chicory, had highest concentrations of $\mathrm{Na}$ at both high and low soil QT Na. Ryegrass and white clover had moderate Na content at high soil Na but ryegrass appeared to be less sensitive to low soil Na. Although cocksfoot is classified as a natrophile and it had high herbage $\mathrm{Na} \%$ at high soil $\mathrm{Na}$, it was sensitive to low soil $\mathrm{Na}$. The very low soil QT Na of 2 at Mt Grand resulted in all species except plantain and chicory having $<0.04 \% \mathrm{Na}$ in their herbage. Merino ewes and lambs, which were present when coarse salt $(\mathrm{NaCl})$ was spread at rates ranging from 50 to $300 \mathrm{~kg} / \mathrm{ha}$, were strongly attracted to $+\mathrm{NaCl}$ plots on south-facing Mt Grand pastures. In two days the sheep grazing and trampling increased bare ground from $25 \%$ before salt was spread to between 40 and $63 \%$. It was concluded that natrophobic species grown on inland soils with soil QT $\mathrm{Na}<5$ are likely to be deficient for sheep; all species except plantain and chicory will produce deficient herbage $(<0.04 \%)$ if soil QT Na is 2 or less and lactating Merino ewes grazing $\mathrm{Na}$ deficient pasture will be strongly attracted to areas where coarse salt is spread. The increase in $\%$ bare ground resulting from sheep seeking salt may provide a tool for enhancing the establishment of pasture seeds broadcast on to hill country.
\end{abstract}

Keywords: grazing behaviour, natrophile, natrophobe, pasture sodium, sheep pastures, sodium deficiency, soil sodium

\section{Introduction}

Areas in New Zealand where sodium ( $\mathrm{Na}$ ) deficiency in livestock grazing pasture may occur were defined by Smith \& Middleton (1978). Responses by livestock to $\mathrm{Na}$ supplementation were most likely in inland areas away from coastal sea spray inputs of salt $(\mathrm{NaCl})$ such as the North Island Central Plateau, Marlborough and Central Otago.

However, their work was derived from mixed pasture samples which were likely to have been dominated by ryegrass and white clover. Both those species normally have high levels of $\mathrm{Na}$ in their herbage and are classed as natrophiles. Sheep pastures in the areas where $\mathrm{Na}$ is likely to be deficient are not always dominated by ryegrass and white clover. On moist hill country, browntop is likely to dominate and the area in lucerne on plains, terraces and fans is increasing in summer dry environments. Both those species are natrophobes which retain $\mathrm{Na}$ in their roots and normally have less than $0.10 \% \mathrm{Na}$ in their herbage. Livestock responses to $\mathrm{Na}$ supplementation are therefore most likely in areas with low soil $\mathrm{Na}$ and where their diet is dominated by natrophobic species.

The recent review of sodium requirements for temperate pastures in New Zealand by Edmeades \& O'Connor (2003) confirmed the Na contents in mixed pasture required for sheep proposed by Towers \& Smith (1983). They stated that $0.04 \% \mathrm{Na}$ in herbage DM will be deficient for sheep maintenance and lambs while $0.07 \% \mathrm{Na}$ should provide sufficient $\mathrm{Na}$ for adult sheep maintenance and lamb growth. Ewes at flushing and during lactation require more $\mathrm{Na}$ and $0.05 \% \mathrm{Na}$ (deficient) and $0.09 \% \mathrm{Na}$ (adequate) were proposed.

Our interest in the adequacy of $\mathrm{Na}$ in sheep diets came from the wide variation in salt use between pastoral farms in susceptible areas and also variation between farms in salt supplementation for sheep grazing lucerne. Some farmers regard salt as essential for their stock health and productivity while their neighbours use little or no salt.

The Lincoln University light land farm, Ashley Dene, has over $30 \%$ of its area in lucerne and uses no salt. Experiments at Ashley Dene with lambs (autumn 2002) and hoggets (spring 2002) grazing on lucerne failed to show live weight gain responses to salt supplementation 
(Aspinall 2002; Lucas unpublished). Ashley Dene is only $24 \mathrm{~km}$ from the coast and mature lucerne in autumn had $0.10 \% \mathrm{Na}$ and $0.05 \% \mathrm{Na}$ in spring. These concentrations were greater than expected for lucerne and probably explained the lack of response by young sheep to salt blocks.

The lack of liveweight gain responses to salt at Ashley Dene has encouraged further work which aims to characterise the influence of distance from the sea on soil and herbage $\mathrm{Na}$ concentrations in the wide range of species found in dryland sheep pastures. Also, we have identified Mt Grand, the Lincoln University high country farm in the upper Clutha basin, as an ideal property for studies on $\mathrm{Na}$ in a pastoral system. No salt has been used on Mt Grand for at least 15 years, Quick test (QT) Na in top soil is 2, natrophobic species all have $0.01 \mathrm{Na} \%$ or less in their herbage dry matter (DM) and natrophilic species average $0.02 \% \mathrm{Na}$. In theory, sheep and cattle on Mt. Grand should be Na deficient but livestock health and productivity appears to be satisfactory.

This paper describes three pieces of related work on aspects of $\mathrm{Na}$ deficiency in Canterbury and Central Otago sheep pastures:

i) influence of distance from the coast on $\mathrm{Na}$ concentration in soils and herbage.

ii) the relationship between soil QT $\mathrm{Na}$ and the prediction of herbage $\mathrm{Na}$ content in a range of species.

iii) preliminary observations of grazing behaviour by lactating Merino ewes when coarse salt was spread on $30 \times 8 \mathrm{~m}$ plots on Mt Grand south-facing pastures.

iv) a possible current source of $\mathrm{Na}$ for Mt Grand livestock.

\section{Rakaia transect Methods}

Plant samples were collected during autumn 2002 from 12 sites within $20 \mathrm{~km}$ of the south bank of the Rakaia River. All sites had soils with greywacke parent material. The transect extended west from the coast for $110 \mathrm{~km}$ over the Canterbury plains and up the Rakaia gorge to Glenfalloch Station.

Where possible, sites were chosen so that samples of browntop, cocksfoot, perennial ryegrass and white clover could all be collected from the same paddock. Areas near gates, troughs, roadsides, dung and urine patches were avoided (Aspinall 2002).

\section{Results}

Proximity to the coast had a major effect on $\mathrm{Na}$ content in all species. Herbage from the site closest to the coast at the top of a $13 \mathrm{~m}$ cliff overlooking the ocean had a mean $\mathrm{Na}$ content of $1.9 \%$. Mean values ranged between 0.3 and $0.2 \% \mathrm{Na}$ between 5 and $20 \mathrm{~km}$ from the coast but from $40 \mathrm{~km}$ to $110 \mathrm{~km}$, mean values declined from 0.10 to $0.07 \% \mathrm{Na}$ (Figure 1).

There were fluctuations in ryegrass and white clover $\mathrm{Na}$ contents before $40 \mathrm{~km}$ inland but $\mathrm{Na}$ contents were generally between 0.40 and $0.15 \%$. At 40 and $65 \mathrm{~km}$ inland ryegrass had $\mathrm{Na}$ contents of 0.17 and $0.16 \%$. Further inland from $80 \mathrm{~km}$, ryegrass Na content averaged $0.10 \%$. After its high values near the coast, white clover decreased to $0.11 \% \mathrm{Na}$ at $40 \mathrm{~km}$ inland and remained at about $0.10 \% \mathrm{Na}$ through to $110 \mathrm{~km}$ from the sea.

Sodium contents for herbage from the natrophobe browntop, averaged $0.05 \%$ from $10 \mathrm{~km}$ to $110 \mathrm{~km}$ and between $75 \mathrm{~km}$ to $110 \mathrm{~km}$ from the coast there were 4 samples which were below the value of $0.05 \% \mathrm{Na}$ suggested as deficient for lactating ewes. The values obtained for cocksfoot, which was classified as a natrophile by Smith et al. (1978), were similar to, or less than, browntop from $20 \mathrm{~km}$ to $75 \mathrm{~km}$. At the 2 most inland sites cocksfoot samples had $\mathrm{Na}$ contents similar to ryegrass $(0.08$ to $0.07 \%)$ but less than white clover (Aspinall 2002).

\section{Correlation of plant and soil Na values}

No soil samples were collected on the 2002 Rakaia 
Figure 2 Relationship between soil QT Na levels and distance from the coast. $\left(y=18.311 x^{0.328} ; r^{2}=0.5805\right)$.

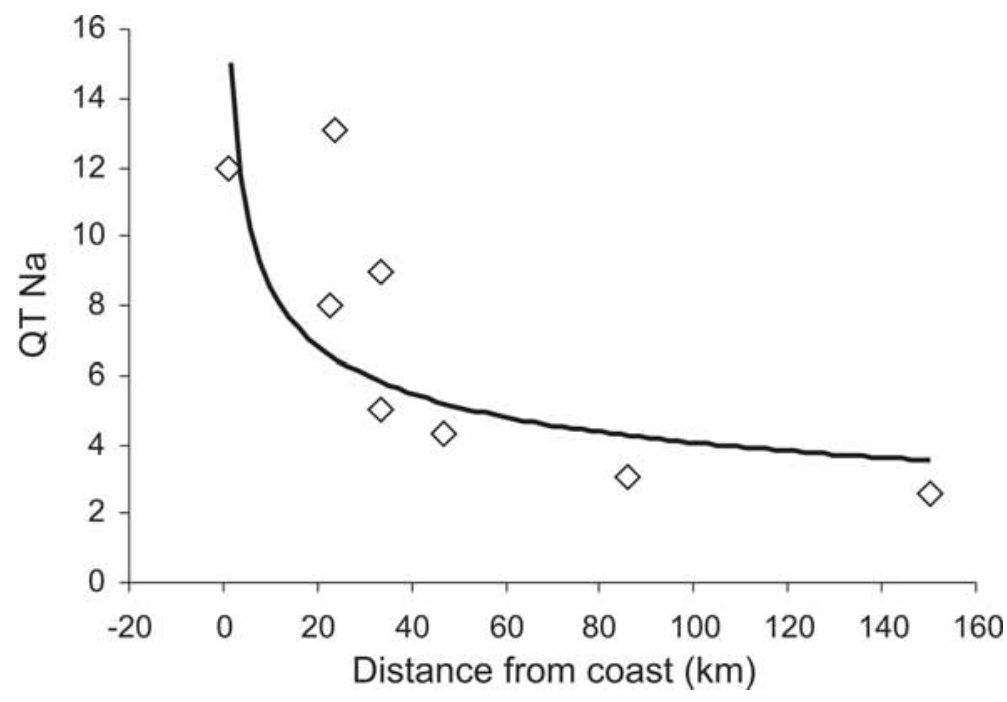

distance from the coast and the soil QT sodium levels.

Pasture and forage species $\mathrm{Na}$ content in herbage DM from 30 different paddocks on 8 farms are listed in Table 1 for sites with soil QT Na values of 5 or more and for sites with QT $\mathrm{Na}$ of $<5$. Species with less than 2 samples for each QT Na category were omitted from the table. This division of QT Na values at 5 was proposed by Edmeades \& O’Connor (2003). They concluded that: "the practical goal to optimise production should be to maintain pasture $\mathrm{Na}$ concentrations at greater than $0.10 \%$ (soil QT Na $>5$ ) by regular monitoring and the application of $\mathrm{Na}$ fertiliser or by supplementing transect study. The 2003 study aimed to relate soil QT $\mathrm{Na}$ to herbage Na content from a range of pasture species found in sheep pastures.

\section{Field survey}

In autumn 2003, soil and plant samples were taken from 8 farms ranging from $1 \mathrm{~km}$ from the east coast at Wakanui to $150 \mathrm{~km}$ at Mt Grand. As many common pasture species as possible were collected from each site. Reproductive tillers and dead material were rejected from samples (Hight 2003).

\section{Correlation results}

The three farms more than $40 \mathrm{~km}$ from the sea had QT $\mathrm{Na}$ values of less than 5 while the 5 sites closer to the sea had QT Na values ranging from 5 to 14 . The correlation between soil QT and distance from the east coast was significant with an $r^{2}$ value of 0.58 . Figure 2 shows the inverse relationship (negative $\mathrm{x}$ exponent) between the the diet with the addition of $\mathrm{Na} . . . . . . . . .$. '

Data presented in Table 1 are not exhaustive in species number nor, in some cases, are there enough samples to make strong generalisations but some can be made with certainty. For instance, Caucasian clover $(0.02 \% \mathrm{Na})$ and lucerne $(0.06 \% \mathrm{Na})$ in soils with QT $\mathrm{Na}>5$ are clearly natrophobes while the herbs, chicory and plantain in particular, are obvious natrophiles with 0.09 and $0.25 \%$ $\mathrm{Na}$ in their herbage from soils with QT $\mathrm{Na}<5$.

The browntop values reflect its natrophobe classification. Ryegrass tended to maintain its herbage $\mathrm{Na}$ content at over $0.10 \%$ in soils with low QT Na values more readily than cocksfoot. The relationship for ryegrass between soil and herbage $\mathrm{Na}$ was not strong $\left(\mathrm{r}^{2}=0.39, \mathrm{P}\right.$ $<0.10$ ). Out of 8 ryegrass samples summarised in Table 1 , one value of $0.03 \% \mathrm{Na}$ from soil QT Na of 2 was less than $0.11 \% \mathrm{Na}$ in the herbage. In contrast the 9 cocksfoot samples had a strong linear relationship between soil $\mathrm{Na}$ and herbage $\mathrm{Na}\left(\mathrm{r}^{2}=0.83, \mathrm{P}<0.001\right)$ (Hight 2003).

Table 1 Mean Na content of herbage from pasture and forage species collected from paddocks where soil QT $\mathrm{Na}$ values were less than, or more than 5. Numbers of samples are given in brackets (Hight 2003).

\begin{tabular}{llrrr}
\hline Species & \multicolumn{2}{c}{$\begin{array}{c}\text { QT Na less than 5 } \\
\text { Na \% in herbage }\end{array}$} & \multicolumn{2}{c}{$\begin{array}{c}\text { QT Na more than } 5 \\
\text { Na \% in herbage }\end{array}$} \\
\hline Perennial ryegrass (Lolium perenne) & 0.07 & $(2)$ & 0.14 & $(6)$ \\
Cocksfoot (Dactylis glomerata) & 0.06 & $(5)$ & 0.16 & $(4)$ \\
Browntop (Agrostis capillaris) & 0.05 & $(2)$ & 0.11 & $(2)$ \\
White clover (Trifolium repens) & 0.05 & $(10)$ & 0.16 & $(15)$ \\
Caucasian clover (T. ambiguum) & 0.02 & $(2)$ & 0.02 & $(2)$ \\
Sub clover (T. subterraneum) & 0.02 & $(2)$ & 0.34 & $(2)$ \\
Lucerne (Medicago sativa) & 0.05 & $(10)$ & 0.06 & $(33)$ \\
Plantain (Plantago lanceolata) & 0.25 & $(3)$ & 0.60 & $(11)$ \\
Chicory (Cichorium intybus) & 0.09 & $(3)$ & 0.70 & $(10)$ \\
Turnip leaf (Brassica campestris) & 0.08 & $(3)$ & 0.13 & $(2)$ \\
\hline
\end{tabular}


Table 2 Mean soil quick test values, macronutrient concentrations and botanical composition (cover \%) before spreading salt and fertilisers on 3 south-facing paddocks at Mt Grand in early-December 2003.

\begin{tabular}{lccccccc}
\hline Soil QT & $\mathrm{pH}$ & $\mathrm{P}$ & $\mathrm{S}$ & $\mathrm{Ca}$ & $\mathrm{Mg}$ & $\mathrm{K}$ & $\mathrm{Na}$ \\
& $5.4 \pm 0.3$ & $16 \pm 6.3$ & $10 \pm 5$ & $6.6 \pm 3.1$ & $26 \pm 11.8$ & $10 \pm 2.4$ & $2 \pm 0.4$ \\
\hline Herbage & & & & & & & \\
macronutrients \% & $\mathrm{N}$ & $\mathrm{P}$ & $\mathrm{S}$ & $\mathrm{Ca}$ & $\mathrm{Mg}$ & $\mathrm{K}$ & $\mathrm{Na}$ \\
Cocksfoot & 1.8 & 0.25 & 0.27 & 0.17 & 0.15 & 2.1 & 0.013 \\
Tall oat-grass & 2.1 & 0.31 & 0.21 & 0.24 & 0.12 & 2.7 & 0.007 \\
Sweet vernal & 1.2 & 0.20 & 0.13 & 0.18 & 0.10 & 1.1 & 0.010 \\
White clover & 3.3 & 0.18 & 0.17 & 0.50 & 0.29 & 2.0 & 0.016 \\
\hline Botanical & Cocksfoot & Tall oat- & Sweet & Clover & Dicot. & Bare ground \\
composition & \multicolumn{2}{c}{ grass } & vernal & & weed & \& litter & \\
Cover (\%) & 20 & 6 & 17 & 15 & 17 & 25 & \\
\pm sd & 12.2 & 7.0 & 10.2 & 11.5 & 14.7 & 14.6 & \\
\hline
\end{tabular}

\section{Mt Grand: a sodium deficient farm?}

Mount Grand (2131 ha) is about $5 \mathrm{~km}$ south-east of the south end of Lake Hawea. The farm runs fine wool Merino sheep and a limited number of beef cattle. It has an altitudinal range of $400 \mathrm{~m}$ to $1400 \mathrm{~m}$ and mean annual rainfall is about $700 \mathrm{~mm}$ on the lower altitude blocks. Mt Grand is $150 \mathrm{~km}$ from the east coast and $85 \mathrm{~km}$ from the west coast. No salt is used on the property. Pastures below about $900 \mathrm{~m}$ are regularly topdressed with sulphur superphosphate. Top soil $(0-75 \mathrm{~mm})$ QT Na values average 2 . Natrophobic plant species are always deficient in Na relative to the $0.04 \%$ Na required in dry sheep diets and most natrophilic species are also normally less than $0.04 \% \mathrm{Na}$ (Tables 1 and 2).

\section{Study site}

Three south and south-east facing paddocks $(50,80$, $185 \mathrm{ha}$ ) on Mt Grand were used. The south-facing hill pastures of Mt Grand farm at 500-800 $\mathrm{m}$ are dominated by 3 grass species, cocksfoot, tall oat-grass and sweet vernal. The dominant legumes are white clover and suckling clover on frequently grazed areas and stock camps but they are minor components on the less intensively grazed steeper mid-slopes. The flat areas $\left(<10^{\circ}\right.$ slope $)$ with greater fertility reflect close frequent grazing with shorter grass and hence minimal shade on the clover. This results in increased clover content and grasses benefit from clover nitrogen $(\mathrm{N})$ fixation plus the increased amounts of animal dung and urine. Herbage is also younger, of greater nutritive value and more attractive to sheep. The mid-slope steep areas $\left(>10^{\circ}\right)$ are less preferred and under-grazed. The grasses become $\mathrm{N}$ deficient and clumpy and progressively less attractive to livestock.

Management alternatives are sought to improve pasture quality and better utilise pasture from the steeper under-grazed areas. More frequent intensive grazing could be expected to improve pasture quality. This would result in greater production of total energy, more clover and increased animal production. The provision of nutrients that are deficient (crude protein, energy and $\mathrm{Na}$ ) in these pastures will improve pasture feeding values and grazing preferences for sheep.

The objectives were to:

i) measure $\mathrm{Na}$ in pasture species and soil.

ii) determine if sheep can detect and show a preference for salt.

\section{Methods}

Samples were taken in early December 2003 to characterise $\mathrm{Na}$ in soil and plant samples. Soil and subsoil samples from 3 south-facing paddocks were taken for chemical analyses before fertilisers and salt were spread. Pasture ground cover was visually estimated by placing randomly $10 \times 0.1 \mathrm{~m}^{2}$ quadrats $(5$ track and 5 bank) per plot on 9 December 2004. Pasture samples were separated into cocksfoot, tall oat-grass, sweet vernal and white clover, dried for 48 hours at $70^{\circ} \mathrm{C}$, and ground to $<1 \mathrm{~mm}$ to measure macronutrient (nitrogen $(\mathrm{N})$, phosphorus $(\mathrm{P})$, potassium $(\mathrm{K})$, sulphur $(\mathrm{S})$, calcium $(\mathrm{Ca})$, Na contents.

Two experiments to determine if sheep would show a preference for coarse salt when spread on small areas of pasture were initiated after soil and plant samples were collected. The urea and sulphur superphosphate treatments were also included to observe sheep and pasture responses to those fertiliser materials with and without salt.

(a) Five rates of coarse agricultural salt $(0,50,100$, 150 and $300 \mathrm{~kg} / \mathrm{ha}$ ) were spread on $10 \times 5 \mathrm{~m}$ plots in Valley paddock. Three replicates of the experiment were established on 10 December 2003.

(b) Two replicates in Watties and one in Broad Leaf paddocks of a $2^{3}$ factorial experimental design ( 8 treatments) were established on 9 December 2003. The three factors were $\mathrm{Na}, \mathrm{N}$ and $\mathrm{P}+\mathrm{S}$ applied as $150 \mathrm{~kg} /$ ha sodium chloride $(\mathrm{NaCl}), 100 \mathrm{~kg} / \mathrm{ha} \mathrm{N}$ as 
Table 3 Bare ground and litter (cover \%) 2 days after spreading urea (N), sulphur superphosphate (SP) and salt (Na) at Mt Grand on 11 December 2003.

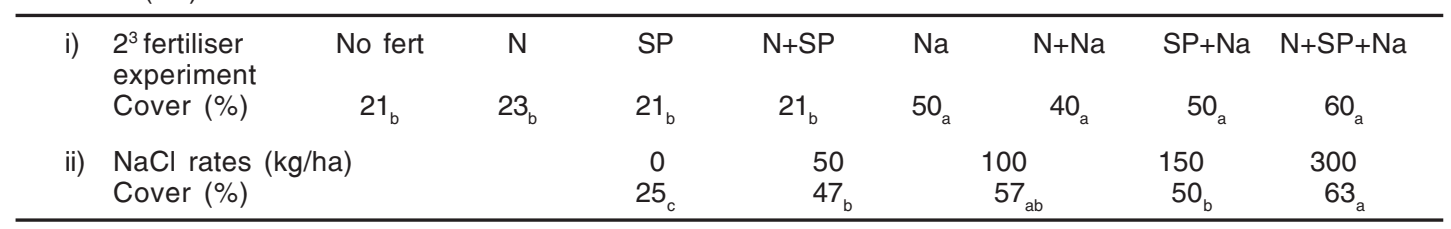

urea $(46 \% \mathrm{~N})$ and $500 \mathrm{~kg} / \mathrm{ha} 19 \%$ sulphur superphosphate. Fertilisers were spread on $30 \mathrm{x}$ 8 m plots.

\section{Results}

The satisfactory QT levels of Olsen P, sulphate-S, QT $\mathrm{Ca}$, QT Mg and QT $\mathrm{K}$ in the soil resulted in grass herbage which was deficient only in $\mathrm{N}$ and $\mathrm{Na}$. Differences in $\mathrm{N}$ content between the grasses (Table 2) reflected their reproductive development (Smetham 1973). Tall oat-grass, with highest $\mathrm{N}$ content, was the least mature with $20 \%$ of its tillers reproductive. Cocksfoot had $45 \%$ reproductive tillers and all the sweet vernal tillers were reproductive.

The $15 \%$ clover cover during warm moist conditions in early December suggested that clover DM contribution to total pasture annual production would be less than $10 \%$ and hence $\mathrm{N}$ fixation/ha/year would be limited.

All 3 grasses had $<0.015 \%$ Na which would supply herbage with less than $40 \%$ of the Na concentration required by lambs and $30 \%$ of the $\mathrm{Na}$ concentration needed by lactating ewes. White clover with $0.016 \% \mathrm{Na}$ was also deficient for sheep.

Ewes and lambs were set stocked at 5 ewes/ha during lambing and were present in the three paddocks when fertilisers and coarse salt were spread on the plots. The sheep were strongly attracted to the plots where salt was applied and their intensive trampling when seeking the salt resulted in a high proportion of turf damage and a significant increase in bare ground plus litter cover (Table 3).

\section{Discussion}

In Canterbury the coastal influence of salt spray on soil and plant $\mathrm{Na}$ contents declines at about $40 \mathrm{~km}$ inland (Figure 1). This may relate to the extent of the easterly wind which is dominant near the east coast. Further inland, natrophobic forage species may be deficient in $\mathrm{Na}$ for sheep diets. Natrophilic species may also be deficient $(<0.04 \% \mathrm{Na})$ in inland basins such as the upper Clutha valley where topsoil QT Na is 2 or less.

Further work is required to define the status of common palatable pasture weeds and the seasonal variations which may be expected in plant $\mathrm{Na}$ content. The effects of reproductive development, age of herbage and current rate of growth in relation to plant $\mathrm{Na}$ status all need better understanding. Farmers could then manage the $\mathrm{Na}$ nutrition of their livestock more efficiently.

Although plant species are classified as either natrophobes or natrophiles there are wide variations between natrophilic species in their ability to accumulate high concentrations of $\mathrm{Na}$ in their leaves in soils with QT Na of 5 or more (Table 1). Plantain had the highest $\mathrm{Na}$ content at all soil $\mathrm{Na}$ levels and if included in pasture mixtures it could be expected to increase the average $\mathrm{Na}$ content of herbage on offer.

Most field experiments with Na supplementation on temperate pastures have been conducted on ryegrass/ white clover in humid climates using dairy cows. Sheep pastures in sub-humid climates and in lower fertility humid areas are likely to include species such as cocksfoot and browntop. They may also have different responses from ryegrass to the range of soil $\mathrm{Na}$ values. For instance, cocksfoot appears to be more sensitive to low soil $\mathrm{Na}$ than ryegrass.

The use of coarse salt to attract sheep to under-grazed pasture areas within large hill blocks ( 60 to $185 \mathrm{ha}$ ) was demonstrated in a spectacular manner at Mt Grand. The craving for salt by the lactating Merino ewes may have been exaggerated by their physiological state. The rapid increase in bare ground \% over a two day period by sheep seeking salt indicated that this strategy could be used to enhance establishment success of seed broadcast on to hill country.

Spreading salt over pasture in the absence of livestock with the objective of increasing uptake of $\mathrm{Na}$ by pasture needs to be investigated in detail. The duration of the effect of salt on pasture $\mathrm{Na}$ content will vary with soil type and rainfall. While a primary $\mathrm{Na}$ deficiency in livestock may be overcome by topdressing with salt, the main use for spreading salt on hill country could be to manipulate grazing behaviour. Salt spread on steep, under-grazed, mid-slope pasture may lead to improved utilisation of mature unpalatable grasses. Areas of scrub sprayed with herbicides would be more attractive to stock and scrub regeneration would be better controlled if salt was spread on sprayed areas.

The level of $\mathrm{Na}$ deficiency in livestock diets will probably affect the way sheep and cattle respond to targeted salt applications. The reliability of animal 
grazing responses in relation to their $\mathrm{Na}$ status needs to be defined. In the meantime we can report that the apparent dilemma of the productive sheep and cattle in the $\mathrm{Na}$ deficient environment of Mt Grand has been partially explained. In April 2004 six banks on the sides of vehicle tracks on Mt Grand hill blocks were sampled where there were signs that sheep may be eating into the sub-soil. Quick test Na values from banks were 3, 4, 5 , 9, 28 and 57. The three lowest values were from south faces and the high values from drier north faces. At the site with QT Na of 57 there were obvious sheep tooth marks in the sub-soil bank between 40 and $100 \mathrm{~cm}$ depth.

\section{Conclusions}

1. Inland areas in Canterbury and Otago which are more than $40 \mathrm{~km}$ from the east coast are likely to have soil QT Na values of less than 5 .

2. Results indicate $\mathrm{Na}$ deficiency in sheep pastures may be expected when natrophilic species such as white clover, ryegrass and cocksfoot are growing in soils with QT Na values of 2 or less.

3. When sheep intakes are dominated by natrophobic species such as lucerne or browntop Na deficiency is likely if soil QT Na values are less than 5 .

4. In a $\mathrm{Na}$ deficient environment where pasture on offer has less than $0.02 \% \mathrm{Na}$ and the soil QT Na is 2, lactating ewes and lambs will be attracted to coarse salt spread on small areas which are undergrazed.

5. Sheep trampling when seeking newly spread salt on targeted areas may be a useful tool to aid establishment of seed broadcast over hill country.

6. Sheep may supplement their $\mathrm{Na}$ intake in $\mathrm{Na}$ deficient environments by licking/eating salt enriched sub-soils where erosion or hill tracks expose the sub-soil.

\section{ACKNOWLEDGEMENTS}

Struthers Trust for funding Dr Nerea Mandalaniz field studies at Mt Grand during her post- doctoral year at Lincoln University; Dr Keith Pollock for assistance with data analyses; Ben Gillespie, David Monks, Hayden Peter and Txarli Ruiz for field assistance at Mount Grand; Gordon Meikle, Mt Grand Farm Manager and Tony Whatman, Lincoln University Director of Farms for advice and encouragement.

\section{REFERENCES}

Aspinall, R.J. 2002. Sodium deficiency in sheep pastures. B.Agr.Sc Honours dissertation, Lincoln University.

Edmeades, D.C.; O'Connor, M.B. 2003. Sodium requirements for temperate pastures in New Zealand: a review. New Zealand Journal of Agricultural Research 46: 37-47.

Hight, L.J. 2003. Predicting the likelihood of animal sodium deficiencies based on soil and herbage concentrations. B.Agr.Sc. Honours dissertation, Lincoln University.

Smetham, M.L. 1973. Grazing management, pp. 187. In: Pastures and Pasture Plants, Ed. Langer, R.H.M., Reed, Wellington.

Smith, G.S.; Middleton, K.R.; Edmonds, A.S. 1978. A classification of pasture and fodder plants according to their ability to translocate sodium from their roots into aerial parts. New Zealand Journal of Experimental Agriculture 6: 183-188.

Towers, N.R.; Smith, G.S. 1993. Sodium. In: The mineral requirements of grazing animals. Ed. Grace, N.D. New Zealand Society of Animal Production. Occasional Publication No. 9. 